\title{
Inhibitory effects of advanced glycation end products formation and free radical scavenging activity of Cirsium setidens
}

\author{
Taewan Kim ${ }^{1}$, Jaemin Lee ${ }^{2}$, Gyeong Han Jeong ${ }^{3}$, Tae Hoon Kim ${ }^{3 *}$ \\ ${ }^{1}$ Department of Food Science and Biotechnology, Andong National University, Andong 36729, Korea \\ ${ }^{2}$ Department of Oral Pathology, School of Dentistry, Kyungpook National University, Daegu 41940, Korea \\ ${ }^{3}$ Department of Food Science and Biotechnology, Daegu University, Gyeongsan 38453, Korea
}

\section{곤드레 추출물의 최종당화산물의 생성저해 및 라디칼소거 활성}

\author{
김태완 ${ }^{1} \cdot$ 이재민 ${ }^{2} \cdot$ 정경한 $^{3} \cdot{\text { 김태 }{ }^{3}{ }^{3 *}}^{*}$ \\ ${ }^{1}$ 안동대학교 식품생명공학과, ${ }^{2}$ 경북대학교 치의과학과, ${ }^{3}$ 대구대학교 식품공학과
}

\begin{abstract}
Naturally occurring antioxidants, such as polyphenols are widely found in fruits, vegetables, wines, juices, and other plant-based dietary sources and are divided into several sub classes, including phenylpropanoids, flavonoids, stilbenoids, and lignans. As part of the our ongoing search for bioactive food ingredients, the antioxidant and advanced glycation end products (AGEs) formation inhibitory activities of the methanolic extract of the aerial parts of Cirsium setidens were investigated in vitro bioassay system. The antioxidant properties were evaluated through radical scavenging assays using 1,1-diphenyl-2-picrylhydrazyl (DPPH) and 2,2'-azino-bis (3-ethylbenzothiazoline-6-sulphonic acid) $\left(\mathrm{ABTS}^{+}\right)$radicals. In addition, the activity of $C$. setidens against diabetes complications was also tested via AGEs formation inhibition assay. The total phenolic contents were determined using a UV-VIS spectrophotometric method. All tested samples showed a dose-dependent radical scavenging and AGEs inhibitory activities. In particular, the $n$-butanol (BuOH)-soluble portion showed the most potent radical scavenging activities against DPPH and ABTS ${ }^{+}$ radicals with $\mathrm{IC}_{50}$ values of $24.3 \pm 1.7$ and $25.0 \pm 3.3 \mu \mathrm{g} / \mathrm{mL}$, respectively. Futhermore, the inhibition of AGEs formation by the $n$-BuOH-soluble portion $\left(\mathrm{IC}_{50}\right.$ value; $46.0 \pm 1.5 \mu \mathrm{g} / \mathrm{mL}$ ) was higher than that those of the soluble portions for the other solvent. The results showed that $C$. setidens could be considered as an effective source of natural antioxidants and other ingredients.
\end{abstract}

Key words : Cirsium setidens, antioxidant activity, DPPH, $\mathrm{ABTS}^{+}$, advanced glycation end products (AGEs)

\section{서 론}

당뇨합병증의 중요한 원인으로 알도스 환원효소 관련 polyol pathway flux 의 증가, protein kinase $\mathrm{C}$ 의 활성화, 최종 당화산물(advanced glycation end products, AGEs) 생성 증 가 등이 알려져 있으며(1), 이들 원인에 의하여 당뇨병성

*Corresponding author. E-mail : skyey7@daegu.ac.kr Phone : 82-53-850-6533, Fax : 82-53-850-6539

Received 7 March 2016; Revised 30 March 2016; Accepted 4 April 2016.

Copyright (c) The Korean Society of Food Preservation. All rights reserved.
신증, 망막증, 백내장, 동맥경화 등의 합병증을 유발하는 것으로 알려져 있다(2). 특히, 최종당화산물은 고혈당의 조 건에서 환원당과 단백질의 비효소적 반응에 의하여 형성되 며, 한번 생성되면 분해되기가 어려워 정상혈당으로 회복 되어도 분해되지 않고 혈액 단백질이나 여러 조직에 결합하 여 장기 손상을 유발한다(3). 최근에는 당뇨합병증의 예방 및 치료제 개발과 관련하여 최종당화산물의 생성 억제제 및 생성된 AGEs의 조직 내 결합(AGEs-protein cross-link)을 억제하는 물질의 개발이 계속적으로 진행되고 있으며(4), 그중에서도 천연물 중에 존재하는 최종당화산물 생성을 억제하는 물질의 개발이 주목을 받고 있다(5).

또한 고혈당과 단백질의 비효소적 당화과정으로부터 생 
성되는 최종당화산물은 활성산소종(reactive oxygen species, $\mathrm{ROS}$ )에 의해 생성이 가속화되거나 세포표면의 AGEs 수용 체와 결합함으로써 활성산소종의 생성을 유발하여 세포손 상을 유발하거나 당뇨합병증을 유발에 깊이 관여하는 것으 로 보고되어져 있다(6). 이러한 접근방법을 기초로 하여 현재까지 알려진 대표적인 최종당화산물 생성 저해억제물 질로는 aminoguanidine, pyridoxamine 등이 있으며 $(7,8)$, 이 들 중 가장 널리 알려져 있는 최종당화산물 생성억제 물질 인 aminoguanidine이 임상실험에서 독성을 나타내는 것이 보고됨에 따라 보다 부작용이 없는 안전한 최종당화산물 생성저해 물질의 개발이 요구되고 있는 실정이다. 최근에 는 보다 안전하고 우수한 효능을 지닌 새로운 물질발굴을 위하여 천연소재로부터 최종당화산물 생성 저해제 개발을 위한 연구(9)가 활발하게 진행 되고 있으며, 석류나무 (Punica granatum) 껍질, 다래나무(Actinidia arguta) 뿌리, 사철쑥(Artemisia capillaris) 전초 등의 자생약용식물로부 터 최종당화산물의 생성을 효과적으로 저해하는 천연물인 flavonoid, ellagitannin, neolignan 등이 보고되었다(11-13). 곤드레(Cirsium setidens)는 국화과(Compositae)의 다년 생 야생 초본으로서 한방에서는 지상부 또는 뿌리를 약용으 로 이용해 왔으며, 지상부는 개화기에 수확하여 뿌리는 가 을철에 채취하여 말려서 경혈, 지혈, 소종의 효능으로 토혈, 혈뇨, 대하, 간염 및 고혈압 등의 치료에 사용한다고 알려져 있다(14). 곤드레는 고려엉겅퀴라고도 불리며 식이섬유, 비 타민 및 무기질이 함유되어 있으며 매월 5월에 채취하여 식용으로 사용하며(15), 봄에 돋아나는 연한 어린잎과 부드 러운 줄기는 살짝 데쳐서 나물 및 국으로 섭취하며, 줄기껍 질 등은 튀김, 무침, 볶음, 데침 등으로 요리하며 특유의 향미를 느낄 수 있는 차로도 이용된다(16). 천연물로부터 다양한 건강기능성을 나타내는 부작용이 적은 소재의 개발 이 이루어지고 있으며, 산채에는 다양한 기능성을 나타내 는 페놀성 화합물들의 생리활성 성분들을 포함하고 있어 주목을 받고 있다(17). 최근 산채와 관련된 연구결과에 의하 면 곤드레 추출물은 항산화, 항암, 멜라닌 생성 촉진활성을 가진 flavonoid, triterpene 및 coumarin등의 성분이 알려져 있다(18-20). 최근 건강과 관련하여 곤드레의 소비자의 수 요가 증가하고 있는 실정이며 항비만 효능도 보고되어 지고 있다(21). 본 연구에서는 곤드레의 메탄올 추출물 및 각 분획물에 대하여 당뇨합병증과 관련된 최종당화산물 생성 억제 및 항산화 활성을 평가에 활용한 AGEs 및 라디칼 저해 활성평가에서 우수한 효능을 확인하였기에 그 결과를 보고하고자 한다.

\section{재료 및 방법}

재 료

본 실험에 시료로 사용한 곤드레(Cirsium setidens)는 경
북 영양군 수비면에서 2014년도 5월에 채취된 신선한 곤드 레를 사용하였으며, 표본시료는 대구대학교의 식품공학과 천연물화학실험실에 보관하고 있다. 본 실험에서 사용된 시약으로 bovine serum albumin(BSA), 3-morpholinosydnonimine (SIN-1), dihydrorhodamine123(DHR123), aminoguanidine, Folin and Ciocalteau's phenol reagent, gallic acid, 2,2'azinobis-3-ethylbenzothiazoline-6-sulfonic acid(ABTS), 1,1diphenyl-2-picrylhydrazyl(DPPH), (+)-catechin 및 tacrine은 Sigma Chemical Co.(St. Louis, MO, USA) 구입하여 사용하 였고, 그 외에 사용된 용매 및 시약은 모두 일급 이상의 등급을 사용하였다.

\section{추출물의 제조 및 분획}

신선한 곤드레 $5.0 \mathrm{~kg}$ 을 메탄올로 침지추출을 3회 반복하 여 여과한 후 농축하였다. 얻어진 곤드레 메탄올 추출물 $(386.1 \mathrm{~g})$ 에 대해 물에 현탁하여 저극성 용매인 $n$-Hexane 으로 먼저 추출한 후 수층을 다시 ethyl acetate(EtOAc)와 $n$-butyl alcohol $(n-\mathrm{BuOH})$ 을 이용하여 각각 순차적으로 3 회 분획하여 추출하였다. 각 용매추출 분획을 감압 농축하여 건조 시킨 후 각각 $n$-hexane 가용분획 $(193.6 \mathrm{~g})$, EtOAc 가용분획 $(28.6 \mathrm{~g}), n-\mathrm{BuOH}$ 가용분획 $(72.3 \mathrm{~g})$, 물 가용분획 $(74.4 \mathrm{~g})$ 을 각각 얻었으며(Fig. 1) 각 분획물을 대상으로 라 디칼 소거능 및 최종당화산물 생성 저해능 평가를 수행하였 다.

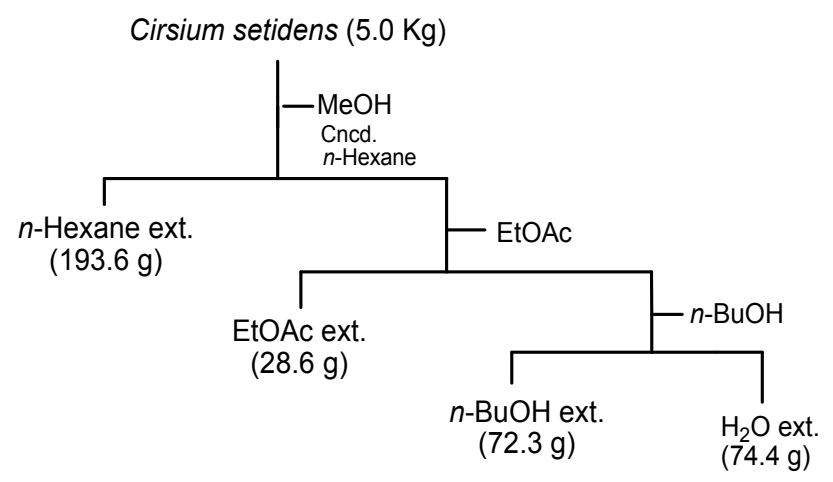

Fig. 1. Liquid-liquid partition of the aerial parts of Cirsium setidens.

\section{$\mathrm{DPPH}$ 라디칼소거능 측정}

곤드레 $70 \%$ 에탄올 추출물의 전자공여능은 Blois 방법 (22)에 따라 측정하였다. 각 시료용액에 $120 \mu \mathrm{L}$ 에 $0.45 \mathrm{mM}$ 의 희석한 1,1-diphenyl-2-picrylhydrazyl (DPPH) 용액 $60 \mu \mathrm{L}$ 을 넣고 교반한 후 15 분간 방치한 다음 $517 \mathrm{~nm}$ 에서 흡광도 를 측정하였다. 전자공여능은 시료용액의 첨가군과 흡광도 차이를 백분율로 나타내었다.

\section{$\mathrm{ABTS}^{+}$라디칼 소거능 측정}

곤드레 메탄올 추출물의 2,2'-azinobis-3-ethylbenzothiazoline6-sulfonic $\operatorname{acid(ABTS)~radical~ㅅㅗㄱㅓㄴㅡㅇㅇㅡㄹ~} \operatorname{Re}(23)$ 의 방법을 
변형하여 다음과 같이 측정하였다. $7 \mathrm{mM} \mathrm{ABTS(in} \mathrm{water)와}$ $2.4 \mathrm{mM} \mathrm{K}_{2} \mathrm{O}_{8} \mathrm{~S}_{2}$ 동량을 혼합 후 실온, 암소에서 12 시간 방치 하여 라디칼의 생성을 유도한 후 $\mathrm{ABTS}^{+}$라디칼 용액을 희석하여 $734 \mathrm{~nm}$ 에서 흡광도 값이 0.7 0.8 정도가 되도록 희석한 후 사용하였다. 희석한 $\mathrm{ABTS}^{+}$라디칼 용액 $100 \mu \mathrm{L}$ 와 곤드레 추출물 $100 \mathrm{\mu L}$ 을 혼합하여 실온에서 7 분간 반응 시킨 후 $734 \mathrm{~nm}$ 에서 흡광도를 측정하였다. 이때 positive control로는 (+)-catechin을 사용하였으며 결과는 시료를 처 리하지 않은 군에 대한 \%로 표시하였다.

\section{In vitro 최종당화산물(AGEs) 생성 저해활성 측정}

최종당화산물 생성 저해활성은 Vinson 및 Howard 등이 행한 방법(24)을 변형하여 실시하였다. $10 \mathrm{mg} / \mathrm{mL}$ 의 알부민 (bovine serum albumin)을 $0.2 \mathrm{M}$ phosphate buffer(pH 7.4)에 용해시키고, $0.2 \mathrm{M}$ 의 fructose와 glucose를 처리한다. 이때 $0.2 \mathrm{M}$ phosphate buffer에 $0.02 \%$ sodium azide를 넣어 반응기 간 동안 박테리아의 생성을 방지하였다. 이 반응액에 추출 물 또는 양성 대조군인 aminoguanidine을 첨가한 후 $37^{\circ} \mathrm{C}$ 에 서 7일 동안 반응시켰다. 배양 후에는 spectroflourometeric detector(Infinite F200, Tecan Austria GmBH, Grödig, Austria)를 이용하여 형광도(Excitation: $350 \mathrm{~nm}$, Emission: $450 \mathrm{~nm}$ )를 측정하였다.

\section{총페놀성 화합물 함량 평가}

총 페놀성 화합물의 함량은 Folin-Denis 방법(25)에 따라 측정하였으며, 추출물 혹은 분획물을 $1.0 \mathrm{mg} / \mathrm{mL}$ 농도로 조제한 후, 시료 $50 \mu \mathrm{L}$ 와 Folin-Denis 시액 $50 \mu \mathrm{L}, 0.7 \mathrm{M}$ 탄산나트륨 포화용액 $50 \mu \mathrm{L}$ 를 차례로 넣은 다음 이것을 잘 혼합하여 실온에서 60 분 방치한 후 UV/VIS 분광광도계 로 $750 \mathrm{~nm}$ 에서 흡광도를 측정하였으며, 표준물질은 gallic $\mathrm{acid}$ 를 이용하여 표준곡선을 작성하여 양을 환산하였다.

\section{결과 및 고찰}

\section{$\mathrm{DPPH}$ 라디칼 소거활성}

보라색을 띄는 DPPH 라디칼은 항산화 활성이 있는 물질 과 반응하게 되면 안정한 형태로 돌아가면서 색이 탈색되고 흡광도 값이 감소하는 원리(26)를 이용한 본실험의 결과로, Table 1에서 나타낸 것처럼 곤드레 메탄올 추출물 및 각 유기용매 분획에 대해서 DPPH 라디칼 소거활성을 평가한 결과, 신선한 곤드레 메탄올 추출물 $\mathrm{IC}_{50}$ 값은 $48.1 \pm 2.1 \mu$ $\mathrm{g} / \mathrm{mL}$ 라디칼 소거능을 나타내었으며, 분획물 중 $\mathrm{EtOAc}$ 층 의 $\mathrm{IC}_{50}$ 값은 $67.9 \pm 3.6 \mu \mathrm{g} / \mathrm{mL}$ 의 라디칼 소거능을 나타내었 다. 특히, $n-\mathrm{BuOH}$ 분획물의 $\mathrm{IC}_{50}$ 값은 $24.3 \pm 1.7 \mu \mathrm{g} / \mathrm{mL}$ 의 우 수한 라디칼 소거활성을 나타내어, positive control로 사용 된 천연 항산화 성분으로 잘 알려져 있는 (+)-catechin과
유사한 활성을 나타냄을 확인하였다. 한편, 물층과 $n$-hexane 분획물의 $\mathrm{IC}_{50}$ 값은 각각 $>500 \mu \mathrm{\mu g} / \mathrm{mL}, 180.3 \pm 13.7 \mu \mathrm{g} / \mathrm{mL}$ 의 비교적 약한 라디칼 소거능을 나타내었다. 최근 페놀성 화 합물의 함량과 DPPH 라디칼 소거능은 밀접한 상관관계가 있다는 보고(27)에 근거하여 곤드래 추출물의 항산화 활성 과 페놀성 화합물 함량과의 연관성을 평가한 결과, Table 1 및 4에서 나타낸 것처럼, DPPH 라디칼 소거능은 페놀성 화합물의 함량이 상대적으로 높은 $\mathrm{EtOAc}$ 및 $n \mathrm{BuOH}$ 층에 서 가장 높은 것을 확인하였고, 그중에서도 라디칼소거 활 성이 강한 $n-\mathrm{BuOH}$ 층에는 $\mathrm{DPPH}$ 라디칼 소거능이 높은 곤 드레의 항산화 활성이 우수한 페놀성 화합물의 존재를 시사 하였다. 또한 다양한 엉겅퀴(Cirsium)속 식물에서 발견되는 flavonoid 화합물(28)인 pectolinarin은 항산화활성 메커니즘 을 통한 간보호 작용을 나타내며(29), 곤드레 주요성분인 qunic acid 유도체인 3,4-di- $O$-caffeoylquinic acid, chlorogenic acid의 우수한 DPPH 라디칼 소거능활성이 보 고되어져 있다(30). 이들 보고된 화합물이외의 DPPH 라디 칼 소거능을 가진 활성성분의 분리 및 동정이 필요하다고 사료된다.

\section{$\mathrm{ABTS}^{+}$라디칼 소거능 측정}

$\mathrm{ABTS}^{+}$라디칼 소거활성은 시료가 항산화력에 의해 $\mathrm{ABTS}^{+}$이 소거되어 본래의 청록색이 탈색되는 정도를 측정 하는 방법으로 천연물로 부터 항산화활성물질 개발을 위한 연구에 광범위하게 이용되고 있다(31). 그 결과 Table 2에서 나타낸 것처럼 곤드레 메탄올 추출물 및 각 유기용매 분획 물에 대해 농도별 라디칼 소거능을 평가하여 활성을 $\mathrm{IC}_{50}$ 값 으로 나타내었으며, 특히 $\mathrm{EtOAc}$ 및 $n-\mathrm{BuOH}$ 분획층물의 $\mathrm{IC}_{50}$ 값은 각각 $69.5 \pm 2.6 \mu \mathrm{g} / \mathrm{mL}, 25.0 \pm 3.3 \mu \mathrm{g} / \mathrm{mL}$ 의 매우 우수 한 라디칼 소거능을 나타내었으며, 이들 활성은 positive control인 (+)-catechin의 활성에 상당하는 효능임을 확인하 였다. 한편, 물층과 $n$-hexane 분획층에서는 상대적으로 낮 은 라디칼소거 활성을 나타내었다(Table 2). 이상의 결과는 Table 4에서 나타낸 것처럼 페놀성 함량 상대적으로 높게 나타난 $\mathrm{EtOAc}$ 층 및 $n \mathrm{BuOH}$ 층에서 $\mathrm{ABTS}^{+}$라디칼을 소거 하는 항산화 활성물질의 존재가 시사되었다. 최근의 연구 결과에 의하면 곤드레에 존재하는 linarin, pectolinarin 등의 플라보노이드류(18) 이외의 qunic acid 유도체인 3,4-di-O-caffeoylquinic acid가 우수한 $\mathrm{ABTS}^{+}$라디칼 소거 활성을 나타내었으며(32) 이들 화합물을 포함한 $n-\mathrm{BuOH}$ 층에 존재하는 라디칼소거 활성물질의 동정이 필요하다고 사료된다.

\section{최종당화산물 생성 저해활성 측정}

최종당화산물은 고혈당의 조건에서 조직에 축적되는 단 백질 당화산물로서 당뇨병 환자에서 정상인보다 수배 이상 함량이 증가하는 것으로 밝혀져 있어 당뇨병성 합병증과 
Table 1. DPPH radical scavenging activity of the methanolic extract of $C$. setidens and its organic solvent-soluble portions

\begin{tabular}{lccccccc}
\hline \multicolumn{1}{c}{ Conc. $(\mu \mathrm{g} / \mathrm{mL})$} & \multicolumn{3}{c}{ Inhibition $(\%)$} & \multicolumn{2}{c}{$\mathrm{IC}_{50}$} \\
$(\mu \mathrm{g} / \mathrm{mL})$
\end{tabular}

1) Inhibitory effects are expressed as the mean $\pm \mathrm{SD}$ of triplicate experiments.

${ }^{2)}(+)$-Catechin was used as a positive control.

Table 2. $\mathrm{ABTS}^{+}$radical scavenging activity of the methanolic extract of $C$. setidens and its $n$-hexane-, EtOAc-, $n$ - $\mathrm{BuOH}-$, and $\mathrm{H}_{2} \mathrm{O}-\mathrm{soluble}$ portions

\begin{tabular}{|c|c|c|c|c|c|c|c|}
\hline \multirow{2}{*}{ Conc. $(\mu \mathrm{g} / \mathrm{mL})$} & \multicolumn{6}{|c|}{ Inhibition (\%) } & \multirow{2}{*}{$\begin{array}{c}\mathrm{IC}_{50} \\
(\mu \mathrm{g} / \mathrm{mL})\end{array}$} \\
\hline & 200 & 100 & 50 & 25 & 12.5 & 6.25 & \\
\hline $\mathrm{MeOH}$ ext. & $98.7 \pm 2.7^{1)}$ & $98.2 \pm 2.5$ & $66.4 \pm 2.0$ & $37.5 \pm 1.6$ & $19.4 \pm 0.8$ & $9.7 \pm 0.7$ & $31.1 \pm 2.1$ \\
\hline$n$-Hexane layer & $41.2 \pm 1.3$ & $36.8 \pm 1.2$ & $22.2 \pm 1.3$ & $10.4 \pm 1.4$ & $4.5 \pm 1.3$ & $3.1 \pm 0.5$ & $>200$ \\
\hline EtOAc layer & $93.5 \pm 2.5$ & $81.6 \pm 2.4$ & $81.2 \pm 1.7$ & $47.5 \pm 1.9$ & $27.3 \pm 1.2$ & $12.7 \pm 0.8$ & $69.5 \pm 2.6$ \\
\hline$n-\mathrm{BuOH}$ layer & $98.2 \pm 2.8$ & $93.6 \pm 2.3$ & $66.4 \pm 2.0$ & $37.5 \pm 1.6$ & $19.4 \pm 0.8$ & $9.7 \pm 0.7$ & $25.0 \pm 3.3$ \\
\hline $\mathrm{H}_{2} \mathrm{O}$ layer & $99.5 \pm 2.4$ & $97.5 \pm 2.3$ & $78.1 \pm 1.6$ & $46.7 \pm 1.3$ & $21.0 \pm 0.8$ & $8.4 \pm 0.6$ & $241.6 \pm 4.6$ \\
\hline$\left.(+)-C a t e c h i n{ }^{2}\right)$ & $99.9 \pm 2.7$ & $99.8 \pm 2.3$ & $94.3 \pm 2.4$ & $70.3 \pm 1.8$ & $68.1 \pm 1.5$ & $36.5 \pm 0.8$ & $13.8 \pm 1.8$ \\
\hline
\end{tabular}

${ }^{1)}$ Inhibitory effects are expressed as the mean $\pm \mathrm{SD}$ of triplicate experiments.

${ }^{2)}$ Used as a positive control.

밀접한 상관성을 갖는 중요한 요인으로 알려져 있다(33). 최근 AGEs의 생성은 당뇨합병증과 밀접한 관계가 있으며 당뇨합병증 치료 및 예방 전략으로 많은 연구가 진행되어 지고 있다. 최근에 개발된 대표적인 최종당화산물 생성 저 해제로는 aminoguanidine이 있으나 독성이 보고되어 보다 안전하고 부작용이 없는 천연물 유래 AGEs 생성 저해제의 개발을 위한 연구가 진행되고 있다. 본 연구에서 곤드레 추출물의 당뇨합병증관련 효능평가를 위해 수행한 실험의 결과 곤드레 메탄올 추출물의 $\mathrm{IC}_{50}$ 값은 각각 $221.1 \pm 7.7 \mu \mathrm{g}$
$/ \mathrm{mL}$ 의 효능을 나타내었고, $n-\mathrm{BuOH}$ 가용분획의 경우 $\mathrm{IC}_{50}$ 값이 $46.0 \pm 1.5 \mu \mathrm{g} / \mathrm{mL}$ 의 상대적으로 강한 활성을 나타났다. 양성대조구인 aminoguanidine의 $\mathrm{IC}_{50}$ 값이 $90.2 \pm 3.2 \mu \mathrm{g} / \mathrm{mL}$ 과 비교해볼 때 $n \mathrm{BuOH}$ 가용분획은 우수한 효능을 확인하 였다(Table 3). 최근의 한약재의 최종당화산물 생성저해활 성 1차 검색 연구(34)에 의하면 계피(Xanthium strumarium) 열매의 $\mathrm{IC}_{50}$ 값은 $16.1 \mathrm{\mu g} / \mathrm{mL}$, 초과(Plantago asiatica) $80 \%$ 에탄올 추출물의 $\mathrm{IC}_{50}$ 값은 $31.4 \mathrm{\mu g} / \mathrm{mL}$, 편축(Polygoni a vicularis) $80 \%$ 에탄올 추출물의 $\mathrm{IC}_{50}$ 값은 $33.1 \mathrm{\mu g} / \mathrm{mL}$ 의

Table 3. Inhibitory effects of $C$. setidens extract on the formation of advanced glycation end products (AGEs) in vitro

\begin{tabular}{|c|c|c|c|c|c|c|c|}
\hline \multirow{2}{*}{ Conc. $(\mu \mathrm{g} / \mathrm{mL})$} & \multicolumn{6}{|c|}{ Inhibition (\%) } & \multirow{2}{*}{$\underset{(\mu \mathrm{g} / \mathrm{mL})}{\mathrm{IC}_{50}}$} \\
\hline & 500 & 250 & 125 & 62.5 & 31.3 & 15.6 & \\
\hline $\mathrm{MeOH}$ ext. & $66.0 \pm 1.3^{1)}$ & $49.8 \pm 1.5$ & $37.1 \pm 1.3$ & $33.2 \pm 0.9$ & $21.7 \pm 0.8$ & $19.3 \pm 0.7$ & $221.1 \pm 7.7$ \\
\hline$n$-Hexane layer & $30.1 \pm 1.2$ & $17.6 \pm 0.8$ & $12.2 \pm 0.5$ & $7.2 \pm 0.6$ & $5.1 \pm 0.5$ & $3.0 \pm 0.6$ & $>500$ \\
\hline EtOAc layer & $29.1 \pm 1.0$ & $21.9 \pm 0.6$ & $17.5 \pm 0.7$ & $8.1 \pm 0.5$ & $7.5 \pm 0.6$ & $5.2 \pm 1.0$ & $>500$ \\
\hline$n-\mathrm{BuOH}$ layer & $86.8 \pm 1.8$ & $73.7 \pm 1.9$ & $70.7 \pm 1.5$ & $57.3 \pm 1.1$ & $41.1 \pm 1.3$ & $32.1 \pm 1.1$ & $46.0 \pm 1.5$ \\
\hline $\mathrm{H}_{2} \mathrm{O}$ layer & $62.2 \pm 2.5$ & $55.6 \pm 1.3$ & $23.0 \pm 0.8$ & $19.6 \pm 0.9$ & $10.1 \pm 0.8$ & $5.1 \pm 0.6$ & $272.3 \pm 4.1$ \\
\hline Aminoguanidine ${ }^{2)}$ & $85.1 \pm 2.6$ & $70.1 \pm 1.8$ & $53.1 \pm 1.6$ & $39.1 \pm 1.3$ & $32.0 \pm 0.7$ & $31.1 \pm 0.7$ & $90.7 \pm 3.2$ \\
\hline
\end{tabular}

\footnotetext{
${ }^{11}$ Inhibitory effects are expressed as the mean $\pm \mathrm{SD}$ of triplicate experiments.
}

${ }^{2)}$ Used as a positive control. 
최종당화산물 생성저해활성을 나타내었으며 이들의 활성 과 곤드레 메탄올 추출물의 $n \mathrm{BuOH}$ 가용부에 상당하는 우수한 활성을 나타내었다. 최근 flavonoid류의 최종당화산 물 생성 저해활성과 관련된 구조-활성 상관관계가 보고되 어 aglycone에 당의 존재가 활성상승에 영향을 미치는 것이 밝혀졌으며(5), quinic acid 유도체의 우수한 최종당화산물 생성 저해활성이 보고(35)되어 져있어 향후 곤드레에 존재 하는 최종당화산물 생성 저해활성물질의 동정 및 활성기작 평가가 필요하다고 사료된다.

\section{총페놀 화합물 함량}

곤드레 추출물 및 각 분획물에 함유하고 있는 총페놀성 화합물의 함량을 Table 4에 나타내었으며, 곤드레 메탄올 추출물은 $1 \mathrm{~g}$ 당 $17.3 \pm 1.5 \mathrm{mg}$ 의 페놀성 화합물의 함량을 확인하였으며, 유기용매 가용부의 경우 $n$-hexane 가용부 $<$ 물 가용부 $<\mathrm{EtOAc}$ 가용부 $<n-\mathrm{BuOH}$ 가용부의 순으로 페놀 성 화합물의 함유량이 증가함을 확인하였다. EtOAc 분획물 은 $1 \mathrm{~g}$ 당 $11.0 \pm 1.7 \mathrm{mg}$ 의 페놀성 화합물을 함유하는 것으로 나타났으며, $n-\mathrm{BuOH}$ 분획물이 $15.2 \pm 1.6 \mathrm{mg}$ 으로 상대적으 로 높은 페놀성 화합물의 함유량을 나타내는 것으로 분석되 었다. 이상의 결과로 부터 곤드레 추출물의 DPPH 라디칼 소거능은 Table 2 및 3 에서 나타낸 것처럼 페놀성 화합물의 함량이 상대적으로 높은 $n-\mathrm{BuOH}$ 가용부 및 $\mathrm{EtOAc}$ 가용부 에서 상대적으로 높은 것을 확인할 수 있었으며, $\mathrm{DPPH}$ 라디칼 소거능과 페놀성 화합물 함량사이에는 밀접한 상관 관계가 있다는 보고(27)와도 일치하는 결과였다.

Table 4. Total phenolic contents of the methanolic extract and or ganic solvent fractions of $C$. setidens

\begin{tabular}{lc}
\hline \multicolumn{1}{c}{ Samples } & Phenolic Contents $(\mathrm{mg} / \mathrm{g})$ \\
\hline MeOH ext. & $17.3 \pm 1.5^{1)}$ \\
$n$-Hexane layer & $6.1 \pm 0.3$ \\
EtOAc layer & $11.0 \pm 1.7$ \\
$n-\mathrm{BuOH}$ layer & $15.2 \pm 1.6$ \\
$\mathrm{H}_{2} \mathrm{O}$ layer & $7.0 \pm 0.5$ \\
\hline
\end{tabular}

${ }^{1)}$ Data represent the mean \pm SD three replications.

\section{요 약}

신선한 곤드레를 메탄올로 침지 추출하여 얻어진 추출물 에 대해 $n$-hexane, EtOAc 및 $n$ - $\mathrm{BuOH}$ 로 극성별 순차 용매 분획을 실시하였고, 얻어진 결과물에 대하여 $\mathrm{DPPH}$ 와 $\mathrm{ABTS}^{+}$radical 소거능 및 최종당화물 생성 저해활성을 평가 하였다. 먼저 DPPH 라디칼 소거활성은 페놀성 화합물의 함량이 상대적으로 높은 $n-\mathrm{BuOH}$ 가용부에서 $\mathrm{IC}_{50}$ 값이 $24.3 \pm 1.7 \mu \mathrm{g} / \mathrm{mL}$ 으로 우수한 DPPH 라디칼 소거능을 확인
하였고, 곤드레 추출물에 존재하는 페놀성 화합물과 라디 칼 소거능과의 연관성을 시사하였다. 또한 $\mathrm{ABTS}^{+}$라디칼 소거능은 $\mathrm{EtOAc}$ 및 $n-\mathrm{BuOH}$ 분획층물의 $\mathrm{IC}_{50}$ 값은 각각 $69.5 \pm 2.6 \mu \mathrm{g} / \mathrm{mL}, 25.0 \pm 3.3 \mu \mathrm{g} / \mathrm{mL}$ 의 라디칼 소거활성이 확인 되었고, 우수한 라디칼 소거 활성물질의 존재가 시사되었 다. 또한, 최종당화물 생성 저해활성을 측정한 결과, $n-\mathrm{BuOH}$ 가용분획에서 $\mathrm{IC}_{50}$ 값이 $46.0 \pm 1.5 \mu \mathrm{g} / \mathrm{mL}$ 로 높은 생 성저해활성을 나타내었으며, 이는 positive control인 aminoguanidine의 $\mathrm{IC}_{50}$ 값인 $90.2 \pm 3.2 \mathrm{\mu g} / \mathrm{mL}$ 과 비교해볼 때 우수한 활성이었으며, 다양한 화합물이 공존하는 추출물 상태의 시료를 단일물질로 정제할 경우 더욱 우수한 효능의 화합물이 존재할 가능성을 시사하였다. 향후 이들 활성물 질 동정을 통한 활성물질의 구조 결정 및 활성 기작에 대한 연구가 필요하며 본 연구결과는 천연물 유래의 라디칼 소거 능 및 AGEs 생성 저해능을 가지는 새로운 천연 기능성소재 발굴을 위한 기초자료로 활용가능하리라 사료된다.

\section{감사의 글}

이 연구는 산림청 지원 산림과학기술개발사업(S111313L050120) 의 지원으로 이루어 졌으며 이에 감사드립니다.

\section{References}

1. Brownlee M (2005) The pathobiology of diabetic complications: A unifying mechanism. Diabetes, 54, 1615-1625

2. Ahmed N (2005) Advanced glycation endproducts-role in pathology of diabetic complications. Diabetes Res Clin Pract, 67, 3-21

3. Huebschmann AG, Vlassara H, Regensteiner JG, Reush JE (2006) Diabetes and advanced glycoxidation end products. Diabetes Care, 29, 1420-1432

4. Huebschmann AG, Vlassara H, Regensteiner JG, Reush J (2007) Diabetes and advanced glycoxidation end products. Annual Review of Diabetes, 51-63

5. Matsuda H, Wang T, Managi H, Yoshikawa M (2003) Structure requirements of flavonoids for inhibition of protein glycation and radical scavenging activities. Bioor Med Chem, 11, 5317-5323

6. Edelstein D, Brownlee M (1992) Mechanistic studies of advanced glycation end product inhibition by aminoguanidine. Diabetes, 41, 26-29

7. Ceriello A (2003) New insights on oxidative stress and diabetic complications may lead to a "casual" 
andtioxidant therapy. Diabetes Care, 26, 1589-1596

8. Stitt A, Gardiner TA, Anderson L, Canning P, Frizzell N, Duffy N, Boyle C, Januszewski SA, Chachich M, Baynes JW, Thorpe SR (2002) The AGEs inhibitor pyridoxamine inhibits development of retinopathy in experimental diabetes. Diabetes, 51, 2826-2832

9. Yokozawa T, Nakagawa T, Terasawa K (2001) Effects of oriental medicines on the production of advanced glycation end products. J Trad Med, 18, 107-112

10. Rahbar S, Figarola JL (2003) Novel inhibitors of advanced glycation endproducts. Arch Biochem Biophys, 419, 63-79

11. Jang DS, Lee GY, Lee Y M, Kim Y S, Sun H, Kim DH, Kim JS (2009) Flavan-3-ols having a 8 -lactam from the roots of Actinidia arguta inhibit the formation of advanced glycation end products in vitro. Chem Pharm Bull, 57, 397-400

12. Ito $\mathrm{H}, \mathrm{Li} \mathrm{P}$, Koreishi $\mathrm{M}$, Nagatomo A, Nishida N, Yoshida $\mathrm{T}$ (2014) Ellagitannin oligomers and a neolignan from pomegranate arils and their inhibitory effects on the formation of advanced glycation end products. Food Chem, 152, 323-330

13. Islam MN, Ishita IJ, Jung HA, Choi JS (2014) Vicenin 2 isolated from Artemisia capillaris exhibited potent anti-glycation properties. Food Chem Toxicol, 69, 55-62

14. Kang IJ, Ham SS, Chung CK, Lee SY, Oh DH, Choi KP, Do JJ (1997) Development of fermented soysauce using Cirsium setidens Nakai and comfrey. J Korean Soc Food Sci Nutr, 26, 1152-1158

15. Chang SY, Song JH, Kwak YS, Han MJ (2012) Quality characteristics of Gondre tofu by the level of Cirsium setidens powder and storage. Korean J Food Culture, 27, 737-742

16. Lee SH, Jin YS, Heo SI, Shim TH, Sa JH, Choi DS, Wang MH (2006) Composition analysis and antioxidative activity from different organs of Cirsium setidens Nakai. Korean J Food Sci Technol, 38, 571-576

17. Larson RA (1988) The antioxidants of higher plants. Phytochemistry, 27, 969-978

18. Yoo YM, Nam JH, Kim MY, Choi J, Park HJ (2008) Pectolinarin and pectolinarigenin of Crisium setidens prevent the hepatic injury in rats caused by D-galactosamine via an antioxidant mechanism. Biol Pharm Bull, 31, 760-764

19. Lee WB, Kwon HC, Cho OR, Lee KC, Choi SU, Baek NI, Lee KR (2002) Phytochemical constituents of Crisium setidens Nakai and their cytotoxicity against human cancer cell lines. Arch Pharm Res, 25, 628-635

20. Ahn MJ, Hur SJ, Kim EH, Lee SH, Shin JS, Kim MK, Uchizono JA, Whang WK, Kim DS (2014) Scopoletin from Cirsium setidens increases melanin synthesis via CREB phosphorylation in B16F10 cells. Korean J Physiol Pharmacol, 18, 307-311

21. Lee YJ, Kim DB, Lee JS, Cho JH, Kim BK, Choi HS, Lee BY, Lee $\mathrm{OH}$ (2013) Antioxidant activity and anti-adipogenic effects of wild herbs mainly cultivated in Korea. Molecules, 18, 12937-12950

22. Blois MS (1958) Antioxidant activity determination by the use of a stable free radical. Nature, 181, 1199-1200

23. Re R, Pellegrini N, Proteggente A, Pannala A, Yang M, Rice-Evans C (1999) Antioxidant activity applying and improved ABTS radical cation decolorization assay. Free Radic Biol Med, 26, 1231-1237

24. Vinson JA, Howard III TB (1996) Inhibition of protein glycation and advanced glycation end products by ascorbic acid and other vitamins and nutrients. J Nutr Biochem, 7, 659-663

25. Singleton VL, Orthofer R, Lamuela-Raventos RM (1999) Analysis of total phenols and other oxidation substrates and antioxidants by means of Folin-Ciocalteu reagent. Methods Enzymol, 299, 152-172

26. Lee SG, Yu MH, Lee SP, Lee IS (2008) Antioxidant activities and induction of apoptosis by methanol extracts from avocado. J Korean Soc Food Sci Nutr, 37, 269-275

27. Wang SY, Chang HN, Lin KT, Lo CP, Yang NS, Shyur LF (2003) Antioxidant properties and phytochemical characteristics of extracts from Lactuca indica. J Agric Food Chem, 51, 1506-1512

28. Jordon-Thaden IE, Louda SM (2003) Chemistry of Cirsium and Carduus. a role in ecological risk assessment for biological control of weeds? Biochem Syst Ecol, 31, 1353-1396

29. Yoo YM, Nam JH, Kim MY, Choi J, Park HJ (2008) Pectolinarin and pectolinarigenin of Cirsium setidens prevent the hepatic injury in rats caused by D-galactosamine via an antioxidant mechanism. Biol Pharm Bull, 31, 760-764

30. Akihisa $\mathrm{T}$, Kawashima $\mathrm{K}$, Orido $\mathrm{M}$, Akazawa $\mathrm{H}$, Matsumoto M, Yamamoto A, Ogihara E, Fukatsu M, Tokuda H, Fuji J (2013) Antioxidative and melanogenesisinhibitory activities of caffeoylquinic acids and other compounds from moxa. Chem Biodiversity, 10, 313-327

31. Re R, Pellegrini N, Proteggente A, Pannala A, Yang M, Rice-Evans C (1999) Antioxidant activity applying an 
improved ABTS radical cation decolorization assay. Free Radic Biol Med, 26, 1231-1237

32. Shang YF, Kim SM, Song DG, Pan CH, Lee WJ, Um $\mathrm{BH}$ (2010) Isolation and identification of antioxidant compounds from Ligularia fischeri. J Food Sci, 75, 530-535

33. Sato T, Iwaki M, Shimogaito $\mathrm{N}$, Wu X, Yamagishi $\mathrm{S}$, Takeuchi M (2006) TAGE (toxic AGEs) theory in diabetic complications. Curr Mol Med, 6, 351-358
34. Jang DS, Lee Y M, Kim Y S, Kim JS (2006) Screening of Korean traditional herbal medicines with inhibitory activity on advanced glycation end products (AGEs) formation. Kor J Pharmacogn, 37, 48-52

35. Jang DS, Yoo NH, Kim NH, Lee YM, Kim CS, Kim J, Kim JH, Kim JS (2010) 3,5-Di-O-caffeoyl-epi-quinic acid from the leaves and stems of Erigeron annuus inhibits protein glycation, aldose reductase, and cataractogenesis. Biol Pharm Bull, 33, 329-333 